Critical Asian Studies 49:4, 2017

\title{
Discipline and Power: Knowledge of China in Political Science
}

\author{
Lin Chun \\ London School of Economics and Political Science
}

\begin{abstract}
Mainstream political science treats China as an anomaly that has not followed the "right" path of development, i.e. a path that confirms the worldview, normative values, knowledge, and expectations of a Euromodern origin. This essay identifies inherent biases in the discipline and shows how the dominant disciplinary approach to Chinese politics has largely remained focused on validating questionable politicalscientific tenets. A tentative proposal is offered for intellectual steps toward more openness and efficacy in disciplinary knowledge production and consumption. The argument is not about overcoming Eurocentrism by promoting Chinese exceptionalism. On the contrary, it is political, and challenges the power of current organizing principles of knowledge in search of a more accurate and cogent understanding of Chinese and global politics.
\end{abstract}

Keywords: political science; disciplinary norms; knowledge and power; study of Chinese politics; counter-hegemonic scholarship.

Correspondent Address: Department of Government, London School of Economics and Political Science, Houghton Street, London, WC2A 2AE, UK. Email: c.lin@1se.ac.uk.

\section{Introduction}

Political science, "that noble science of politics," is a powerful academic discipline that has for more than a century influenced changes in politics and society the world over. Compared, however, with the natural sciences, political science - politically oriented by its nature, inevitably affected by dominant ideologies, and engaging intentional actors possessing agency and reflexive rationality in politics - should be recognized as even softer than the other soft social sciences. ${ }^{2}$ Thus, wherever political scientists may position themselves in a given political spectrum, as a matter of intellectual humility they tend to

1 T.B. Macaulay quoted in Collini et al. 1983, v.

2 While political science cannot be free of theory and value-laden observations and interpretations, we have a desire, nonetheless, to mitigate their effect and pursue "a unified critical judgment" based on "unified logic of [causal] inference" (King, et al. 1994, 3-7). 
admit that their profession may never live up to its lofty ambition of scientific explanation and prediction. Indeed, like the other social sciences, it can be no more than a "science in formation" permanently seeking to surmount obstacles to objectivity. ${ }^{3}$

Aspiring to constructive criticism, I am not concerned with various culture wars nor competing social-scientific methods (of which the strengths or weaknesses depend on how well their specific research topics are chosen and served). Rather my dual goal is to demonstrate how contemporary China is consistently misrepresented in political science despite serious advances in China studies, and explain why the knowledge that follows from this misrepresentation continues to be produced and consumed. I argue that a more conscious effort at corrective renovation is not merely overdue but imperative. China is a testing ground for many received assumptions and conceptions which, although not uncontested, have penetrated academic and policy circles globally, including in China. ${ }^{4}$

I begin with the familiar story of the initially positivist and orientalist propensities of political science. While European Sinology's culturalist presupposition of Chinese otherness was inherited by American area studies in the post-World War II era, as well as communist studies and third world studies in the cold war era, at the core of that process was modernization theory. I then turn to the less discussed assumption that modernity, taken for granted as both concept and political project, anchored an insistence among scholars about China's premodernity and its inability to become fully modern. Following this, I explain how claimed deficiencies in Chinese political development have served to validate norms and normative values central to the discipline's operation. I conclude with a tentative proposal for disciplinary reform, emphasizing the politics of evidence and interpretation. Throughout, I use relevant examples to illustrate where we are and where we can go in our quest for a truth-searching, holistic political science perspective on China and the world.

\section{Disciplinary Parochialism and the Politics of China Studies}

Along with the emerging social sciences in Europe and the United States in the nineteenth century, political science was enhanced by conjoining the expertise of politics and political philosophy. The ethnocentric origin of this discipline is the cause of an enduring difficulty in comprehending societies outside its comfort zone. The generic "human science" of "nomothetic disciplines" is about a Euro-American present that epitomizes universal achievement, ${ }^{5}$ and is thereby inherently narrow in both its empirical and conceptual foundations. Emerging in the aftermath of the American Civil War (18611865), political science assigned itself the mission of re-integrating a society morally and physically torn apart. Over the following one hundread years or so and in exchange with other regions, ${ }^{6}$ as a globalizing intellectual enterprise political science expanded its scope

3 Bailey and Llobera 1981, 8.

4 As noted by Brook and Blue, "Almost all our categories - politics and economy, state and society, feudalism and capitalism - have been conceptualized primarily on the basis of Western historical experience." Brook and Blue 1999, 1. My limited scope of examination in this paper does not include international relations literature.

5 Wallerstein 1991, 97.

6 Adcock, et al. 2009, ch.1. 
to interigate wars, revolutions, national liberation movements, decolonization, and the emergence of a socialist camp. Mostly intact by virtue of its innate confines and political unconscious, the discipline's rein over normative values and legitimating semiotics was bolstered by democratic welfare reforms in post-1945 Europe and North America. Such values and semiotics have since become globally dominant to the extent that the organizing principles of disciplinary knowledge hardly permit diversity.

The fetishes of pure observation, raw experience, unambiguous rationality, and one-way causality were formative influences in the genesis of the social sciences. The "unfortunate positivism" of such impulses, along with the illusion of a value-free science, converged to produce a behavioral revolution in the interwar period. ${ }^{7}$ Behaviorism was then followed, through an epistemological twist, by boldly optimistic leaps to an "end of ideology" and ultimately to a claimed "end of history" itself. In the words of one observer: "Social science ought no longer to concern itself with normative questions - most of which had been resolved - but rather with the positive questions of how to achieve the universally agreed upon normative ends in the most efficient possible manner." Whatever such unilaterally resolved normative questions were, their accompanying individualistic preoccupations in research programs and methodology took a toll on understanding collective sources of power relations in politics, especially for nonEuropean political experiences and social histories. ${ }^{9}$

The rebellious 1960s saw the first iconoclastic defiance of incontestable political science norms. The U.S. civil rights movement, global antiwar protests, and political agitations of third-worldism, feminism, and ecologicalism gained support among radical academics and campus activists. Confidence in the scientific claims of political science was shaken. ${ }^{10}$ However, subsequent anti-positivist and post-behavioral turns ended up being more deconstructive than transformative. The discipline held its ground and claimed a monopoly over the normative vocabulary of freedom and democracy. On the fertile soil of post-communist ruins signposted by American unipolarity, more sophisticated technical versions of the discipline have only thrived.

Rather than offering an analytical history of political science, for the purpose of this paper it suffices to highlight the discipline's orientalist inclination. ${ }^{11}$ Early positivism

7 Haldane quoted in Oakeshott 2004, 45; Sanders 2002; White 1962; Ross 1991, 390, 393-407; Oakeshott 2004, 45.

8 Gilman 2003, 59, 115.

9 See especially critiques of "possessive individualism" by Macpherson 1962 and, by extension, "exclusive private property" in Hann 1998.

10 The shift was marked by a self-critical presidential address at the 1969 American Political Science Association convention. It denounced pretensions of neutrality and uniformity, and positivist empiricism as "an ideology of social conservatism" (Easton 1969, 1052). Later and more bluntly, another former president of APSA admitted that political science was "itself a political phenomenon" and as such "a product of the state" (Lowi 1992, 1). Soon after, Albert Hirschman in an influential review compared "behavioral determinism" unfavorably with narrative depth and interpretative plasticity (1970).

11 "Orientalism" in relation to "cultural imperialism," refers to what Edward Said saw as "a style of thought based upon an ontological and epistemological distinction" between 
was openly underpinned by a European condescension toward Asians' "ignorance and prejudice." ${ }^{12}$ Behind similar depictions lay a comprehensive Eurocentric social and political philosophy. A "generalized slavery" under "oriental despotism" in "shameful stagnation" filled the non-romanticist thread of a bifurcated Occidental discourse, from Montesquieu to Condorcet, and Hegel to Marx. ${ }^{13}$

This is illustrated in its view of China through the grand narrative of modernization. Above all, China has never traversed the required threshold of adherence to liberal democracy, despite the establishment of Asia's first republic (the Republic of China) in 1911 and the social revolution of 1949 that heralded the founding of the Peoples Republic. In Cold War-era area and international studies, "Red China" was viewed as a political foe, reflecting the extent to which American state interests impacted these academic fields. Robert Ward, who was elected president of both the American Political Science Association (APSA) and the Association of Asian Studies (AAS) in 1973, later recalled how the study of those other polities was necessitated by the enormous extension of American "national spheres of interest, concern, involvement, and responsibility." 14 It was the Office of Strategic Services in Washington (the predecessor of the CIA) which institutionalized communist studies in comparative politics programs in the United States. ${ }^{15}$ The remaining relevance of this old story lies in the fact that decades into a post-Cold War era, the baseline ideological and geopolitical obsessions with anti-communism persevere.

Robert McNamara famously reiterated that if the First World War was a chemist's war and the Second a physicist's, Vietnam "might well have to be considered the social scientists' war." 16 The social scientists who believed in American expansion were tasked

East and West, by which "European culture was able to manage - and even produce - the Orient politically, sociologically, ideologically, scientifically, and imaginatively." Said 1978, 2-3.

12 Condorcet 1955, 39.

13 Dawson 1964, ch.1. Worth noting is Marx's intuition of looming revolutionary changes in China and Asia ahead of Europe, which negated the gist of his own "Asiatic mode of production" in line with the Orientalist imagination.

14 Ward 1975, 33. To build a "national program for area studies" was to "penetrate" those socio-psychologically distant countries so as to "give direction to their leaders" and gain control over their conformity. See Robert Hall's 1948 report quoted in Barlow 1997, 224. See also Peck 2006.

15 At the same time a number of leading "China Hands" were persecuted in the McCarthyist hysteria. The Social Science Research Council (SSRC) oversaw the Committee on World Area Research, the Committee on Comparative Politics, and the Far Eastern Association - now the Association for Asian Studies. The first area studies organization in the US was founded in 1943. The Joint Committee on Contemporary China was formed in 1959 under the SSRC and the American Council of Learned Societies. Also involved were big private foundations. 16 Quoted in Marquis 2000, 79. Political scientists from elite U.S. universities and think tanks were involved with counterinsurgency techniques in southern Vietnam, which failed miserably. Meanwhile, liberal-minded specialists advocated agrarian reforms 
"in a government-sponsored quest to keep the nations of the Third World within the Western fold." ${ }^{\prime 7}$ This war in Vietnam was of course lost. But its long shadow still lingers in the uninterrupted application of social science doctrines. ${ }^{18}$ A plain lesson from the American War in Vietnam is that different political-ideological agendas result in different research designs, findings, and policy recommendations.

\section{Modernity: Cultural China and Political Development}

To indicate a connection between American strategic objectives and social science practices is not to dismiss academic integrity as a fiction. The point is that given some magnificent contributions from the study of Chinese politics with a growing consciousness of political science, ${ }^{19}$ it is all the more puzzling that practitioners have stopped short of forcing a disciplinary reform. Rather than challenging anything within the discipline that is problematic, yields from field research seem to have hinged more on conventional conceptualizations. This is superficially logical if one assumes global convergence, in which formerly communist societies have by and large "returned to normality." ${ }^{20}$ Although China nominally remains a communist state, it has doubtlessly changed color without a color revolution. With the demise of historical communism, traditional area studies of former communist societies have been re-branded as "transitional studies," a rubric that accommodates expectations of both marketization and democratization. Yet in the context of the PRC, the vista is of an outsider entering the arena of great power rivalries, a weird mixture of an economic equal who is a cultural alien and political rival. Paradoxically, the discipline's sinological preoccupations and Cold War mindset jointly keep China an entity too distant to be ever absorbable.

Also getting a share of Asian studies where the ethos of culture was salient and cultural peculiarities allowed a "quarantined" "intellectual diaspora,"21 "cultural issues have set the essential research paradigm for the study of Chinese politics." 22 This binary mapping of the political versus cultural is nevertheless a distortion of the actual historical movements of cultural communication and amalgamation. Like other countries in the region, neither homogeneity nor seclusion has ever been the case for China. Yet in the fixed disciplinary eye, "China" is too specific to produce anything generalizable beyond descriptive and self-containing narratives. The area studies approach, in contrast to disciplinary approaches, is all about cultural, historical, and ethnographic specificities, however eloquent or idiosyncratic these may be. As the saying goes, the area specialist

which resembled American rural reconstruction projects in China in the 1930s in the hope of "modernization without revolution." Marquis 2000, 80, 84-94.

17 Marquis 2000, 104.

18 See a case study of the U.S. National Security Education Act 1991 and its implementation through a federal program, which shows how the U.S.-led global order continued to impact Asian studies. Cited in Selden and Boyce 1992.

19 O’Brien 2011, 535. See Perry 1999; Walder 2004; Baum 2007; Carlsen et.al. 2010. 20 Cumings 1997, 5.

21 Ward 1975, 36.

22 Dittmer 1983, 51. 
can at best appreciate the advantages of monolingual social sciences and is destined to be a supplier of raw materials to the generalist who toils to theorize. ${ }^{23}$

It is not uncommon nowadays that the China expert in political science processes (quantitative) data as a comparativist or theorist, but she tends to do it in separate minds. Observing the phenomena through fieldwork belongs to the one and arriving at their analytical assessment to the other. The two processes scarcely cross except in their normative articulation in the academic lingua franca. If first hand information contradicts theoretical conclusions, redress is sought only at the former end. If, for example, intensified conflicts in Xinjiang tell a socioeconomic tale about class inequalities, that tale tends to be downplayed in a black-and-white (and often also with double standards) human rights discourse customary to the discipline. Such a discourse underscores incompatible identities of essentialized ethnicity and religion and often also fatal institutional failures, leaving the riddle of why the violence has intensified only in more recent years unattended. This is because, according to the political science doctrines, the market is good or at least necessary (what about free flow of labor with its politically sensitive demographic repercussion?), and communist rule is bad and incapable of ethnic peace (what about once functional ethnic-regional autonomy in China along with ample historical cases of socialist federations?). ${ }^{24}$ The fact that extensive and interdisciplinary expert analyses have avoided such oversimplifications and offered convincing critiques to account for both commodification and oppression only sharpens the question of why they have had so little impact on the dominant disciplinary perspective. Missing from the latter is an economic transition infused by unconstitutional local policies on language education and religious rituals, corruption and unchecked pre-revolutionary Han chauvinism, in addition to external agitations. ${ }^{25}$

Here comes the catch that Chinese otherness is in essence not a matter of cultural difference (hence limitations of criticizing Eurocentrism and Orientalism) and does not merely reproduce itself by inertia. It is actually instrumental for corroborating what is held true and dear to political science. At issue is thus more than any unequal division of labor that reinforces incongruity between "nomothetic and idiographic knowledge."26 Given a long omitted self-critical rethinking of the discipline's parochial base, calling for cross-fertilizing alone would be fruitless or even lead only to a one-way colonization of seemingly particularistic histories by an illusive universal science.

23 In China studies, "when the Chinese case does not fit prevailing theories, the tendency is to treat China as a unique outlier rather than adjust the theories to accommodate it..." (Dickson 2016, 320).

24 See, for example, Barry Sautman's critiques in 1999 and 2006.

25 Nuanced observations stress also the dynamics of economic globalization which allowed blending of religious and market values when monsteries became profit making nodes along horizontal networks linking local communities and identities to transnational capital (Goossaert \& Palmer 2011: 242). See also Wang 2010; Mackerras 2010; Zang

2012; and Leibold 2013.

26 Wallerstein 1991, 97. 
Political culture, once a key concept of political science's hoped for unified theorization, has turned out to be no answer. ${ }^{27}$ This may sound counter-intuitive, given how such a concept enables the everyday lifeworld of attitudes, morals, and feelings to be analyzed politically, and makes comparative politics globally commensurable. It should also provide for agential preferences and intersubjective subtleties,${ }^{28}$ and hence destabilize positivist propositions. However, once political culture was paired with political development in modernization theory, the two were interlinked and reserved for underdeveloped societies with a "native genius" against modern change. ${ }^{29}$ Writing in the early 1960s, Lucian Pye, former president of APSA, warned that new post-colonial states "pose a challenge for the social sciences" because of their political backwardness. ${ }^{30}$ Long after its heyday, modernization theory - now with its new face of globalization - remains a primary signifier and legitimating benchmark. To those who use it to gauge developments since 1945, private property and liberal democracy are permanent, unquestioned norms that are to be globally homogenized. Leaving aside the deception of global modernity in light of the social and environmental calamities its prime drivers have inflicted upon the world, this one-dimensional temporality continues to rank and control spatialities as "the principal tool of power and domination." 31

Measured by the teleology of modernity and its capitalist hallmarks, China's socialist past and whatever is detectable of that legacy in its present are blamed for a Chinese "self-defeating escapism" or "xenophobia" resentful of the modern West. ${ }^{32} \mathrm{~A}$ cultural judgment is then unequivocally political, for nothing is worthwhile or acceptable "save that in the direction of western experience." 33 Moreover, since modernity is assumed to be a liberal capitalist condition, the revolutionary nationalism of an oppressed people remaking itself into a new historical subject noncompliant with capitalism cannot be modernizational. ${ }^{34}$

27 See the original introduction of the concept in Verba 1965, 518, 526-543. Polling and survey techniques developed in sociology were borrowed to make political culture aggregately measurable.

28 MacIntyre 1973, 172-175. See also Bevir and Rhodes 2006, 70-71.

29 They are twins because comparative political culture assumes "a lead in analyzing, distinguishing, and classifying various types of politics" at various stages of political development (Verba 1965, 5). See also Huntington 1975, 63-65.

30 Pye 1962, vii; 1966, 35-36. For a summary of academic critiques of the political culture approach, see Almond and Roselle 1990, 144-145. Additional problems occur whenever the concept, already biased with unspoken presumptions, is taken as an independent variable and monocausal.

31 Bauman 2000, 9.

32 Landes 1998, 345.

33 Tipps 1973, 213. As such, a stark contrast appears between political culture and its radical negations in the cultural studies crystallized around the same time in the early 1960s and subsequently expanded into subaltern studies and postcolonial critiques. 34 Conviniently forgotten here are how imperialist and colonialist first developers rendered development elsewhere difficult. It was against this background that the modern Chinese nation emerged by acquiring a class-national consciousness, in the sense that 
To the credit of China experts in political studies, the conceptual dictation of political development never gained much ground. But neither was it directly questioned. In a co-edited volume on popular protest in China in the aftermath of Tiananmen, Elizabeth Perry and Jeffrey Wasserstrom proposed a "neoculturalist perspective" that sought "greater maturity and sophistication" in explaining Chinese practices through locally prompted cultural repertoires. "Rather than seeing Chinese politics as forever condemned to a treadmill of repetitive patterns," they wrote, "we look instead for creative deviation and breakthrough." "35 Yet such a breakthrough would require a systematic examination of the transmuted "communist regime" in the first place. A shared conflation of China's pre- and post-reform commitments concealed their vast differences under that label. If culture, always in flux, can be recaptured to facilitate better understanding, widespread social protests since 1989 could be examined with an eye on the socialist past. The phenomenal lack of major revolt even during the famine years (against a strong Chinese tradition of peasant rebellions), for example, cannot be explained away by state control or suppression. Many post-reform changes in culture and society require such historical comparisons to be fully explainable, such as money and cadre status fetishism and reinvented patriarchy and superstition.

If cultural China no longer stands for patrimonial bureaucracy and political stagnation (a center piece of the essentially racist verdict on a defective Orient), the reign of similar presumptions of impeded progress remains in place. For example, with rare exceptions researchers in Chinese politics have no quarrel with positioning China as democracy's adversary, disregarding any serious democratic impetus in its revolutionary history and national development. The teleological bracket of transition to capitalist democracy is where China must fit itself in.

\section{Revolution, legitimacy, and contested regime durability}

To ask whether capitalist democracy is the only legitimate prospect for development sounds superfluous today in a postcommunist environment. But it was once an open question among more historically sensible social scientists. Indeed, a remarkably prolific openness mitigated Cold War rigidities and ideological hindrances. The groundbreaking revolutionary and socialist projects of unifying and developing China were thus honestly appraised by some scholars. The Chinese synthesis of communism and nationalism, revolution and modernization attracted political scientists and historical sociologists as different as Samuel Huntington and Barrington Moore, along with their students and critics. ${ }^{36}$ They saw the communists in power as formidable modernizers, but

"only when a nation became a class ... did it become politically conscious and activist... [as] a nation-for-itself" (Gellner 1983, 121). See also Duara 1995, 12-14.

35 Perry 1994, 2-5. Lampton 1987 on the Chinese communist system as a "bargaining treadmill" is a different and useful description.

36 Among the best known examples, Samuel Huntington stressed state capacity of communist regimes which compared favorably with countries trapped by "ungovernability" (1968, 8, 266); Theda Skocpol demonstrated how non-western social revolutions had "given birth to nations whose power and autonomy markedly surpassed their own pre-revolutionary pasts and outstripped other countries in similar 
distinguished the Maoist model from the Stalinist in economic management and campaign politics. Furthermore, democratic claims from the Chinese experiments accentuated in Maoist populism and "people's democracy" were taken seriously by political scientists such as Charles Lindblom and C.P. Macpherson. Their analyses showed how organic connections between top-down mobilization and bottom-up participation cultivated an active citizenry and high intensity politics. They also argued that the "mass line" and its infrastructural institutions were enabling mechanisms for aggregating popular preferences through grassroots deliberations condusive to democratic policymaking. ${ }^{37}$

More broadly, Charles Tilly invoked "big structures and large processes" as much as "chance and idiosyncrasy" in pursuit of social science knowledge and predictability. Tilly appreciated Mao's articulation of a class-based united front as a strategic prerequisite, emphasizing that a revolution's political alligment shaped the postrevolutionary political landscape. ${ }^{38}$ Mancur Olson was intrigued by the Maoist rationale for combating post-revolutionary bureaucratization through periodic upheavals (akin to direct democracy) - this deliberate Chinese disorder carried a universal message for advanced democracies as well. He argued that the capitalist "corporate-bargaining state" was just as much in need of such upheavals to curb "distributional coalitions" continually forming to monopolize organizational resources to the detriment of fairer distribution. ${ }^{39}$

These arguments are rarely alludded to today and largely have disappeared from both political science and China studies. Yet outstanding examples of a less disciplined political science scholarship certainly exist. In a tradition pioneered by political sociologists Franz Schurmann, Mark Selden, and others, Gordon White read democracy in China as an "unfinished project." Mark Blecher pointed out that unlike most authoritarian regimes, "the Maoist state chose instead to rule by activating society. It wanted believers, not subjects." Sticking to democracy or minzhu's philological meaning, Brantly Womack argued that "democracy in China must be understood and judged in terms of the desires, interests, and situations of the Chinese people" because the question of democracy can only be an endogenous one about "this people's power." 40 Such views are hard to find in current debates because disciplinary "natural selection" silences or amplifies with tangible rewards and punishments. Hence in writing about the merits of"decent democratic centralism" Stephan Angle still has to assert that "we liberals"

circumstances" $(1979,3)$. They confirmed the Machiavellian insight on revolutionary creativity and state power in transforming large, agrarian, illiterate and patriarchal societies.

37 For Lindblom, the Chinese "mass line" ought to be acknowledged in the liberal world as "a form of democracy" $(1977,262)$. By extension, Macpherson considered those nonliberal systems which prioritized public welfare and enjoyed popular support to "have a genuine historical claim to the title democracy" $(1966,3)$. So much so that formal democracy theorists were earnestly baffled, see, for example, Giovanni Sartori 1987, 183-184.

38 See, in particular, Tilly 1975.

39 Olson 1982, 42-47. See also Rose-Ackerman 2003; Harding 1981.

40 Schurmann 1966; Selden 1971; White 1983; Blecher 1997, 220; Womack 1991, 54. 
prefer a (static and painless) Rawlsian scheme. ${ }^{41}$ Instead of scholarly contextualization, any historically influential socialist experiment receives censure by an unholy alliance of official China and professional political science. The result of disciplinary correctness is that both the liberty and tyranny of revolutionary democracy are denied their original connotations, and the whole genre and language of "grand democracy" is vilified and forbidden.

A direct consequence of this reluctance to acknowledge the initial legitimacy of and mass support for the communist revolution in China is that the Chinese Communist party's (CCP) durability cannot be sufficiently explicated. Most attempts are crippled by a neglect of the remaining "dividends" of revolutionary and socialist achievements. The latter, from the standpoint of ordinary Chinese, are separable from indefensible policy blunders. This is also why the call by a group of China experts in the United States to remove the "1949 wall," echoing a revisionist Chinese discourse of "farewell to revolution," is just as untenable. ${ }^{42}$ The reality is that, for majority Chinese citizens, the divide between "old" and "new" China is still meaningful, despite increasingly blurry post-socialist conditions. At stake is not only material wealth and equity, ${ }^{43}$ but also political and cultural recognition, from the dignity of labor, equality, and the solidarity of nationalities to "society's normative infrastructure" in general fostered after 1949. ${ }^{44}$ Without preserving the milestone of 1949 when Chairman Mao proclaimed that "the Chinese people have stood up" at the PRC's founding ceremony, little of China's present transmutation is comprehensible.

Consider three books published in $2016 .{ }^{45}$ David Shambaugh has written extensively on both "atrophy and adaptation" of the CCP but takes a pessimistic turn in China's Future, predicting that "the endgame of Chinese communist rule has now begun." ${ }^{46}$ Employing sweeping guesswork regarding elite politics, he portrays Xi Jinping as a "Maoist conservative," ignoring the leadership's aggressive neoliberal economic

41 Angle 2005, 518, 541.

42 Among others, Esherick 1995 argued for "the need of breaking the 1949 barrier" (41); Cohen (2003) perceived the "diminishing significance of 1949."

43 This dimension is of course essential and an intellectual battlefield. For example, although evidence shows that the Cultural Revolution was a period of productive and scientific growth after a couple of chaotic years (Kraus, 2012, 63-83, using statistics from the political economists Carl Riskin and Barry Naughton), it is insisted in both official Chinese accounts and relevant scholarship that China was brought to the "brink of economic collapse" during this period.

44 Lee 2007, xi.

45 Earlier explanations are widely considered outdated because of Xi Jinping's moves since 2012. Andrew Nathan (2003), for example, explained regime resilience by citing reformed "input institutions," succession procedures, local elections, more meritocratic incentives, and a bolder critical media. More recently, Minxin Pei wrote that the regime's post-Tiananmen survival strategy is exhausted as the "autocratic crony capitalist development model is dead," depicting the "signs of intense elite power struggle, endemic corruption, loss of economic dynamism, and an assertive, high-risk foreign policy" (2015).

46 Shambaugh 2009; 2015; 2016. 
policies and globalist pledge. ${ }^{47}$ Rather than tapping into any of the CCP's remaining resources, Shambaugh's dubious advice includes further financial liberalization.

Conversely, Bruce Dickson is an optimist. Making it clear that his starting point is not democracy as the "inevitable alternative to communist rule in China," he argues that a combination of legitimation, cooptation, and repression has enabled the Party to endure. Besides, as he notes, "there is no other organization with the capability of governing China and holding it together." 48 While debunking the ahistorical banalities around the fashionable question of "will China democratize?"49 Dixon succumbs to the habitual consumption of disciplinarily sanctioned China knowledge which misses some explanatory, path-dependent factors linked to the enduring impact of revolution.

Wenfang Tang's intervention is thus all the more promising as he views the revolutionary past as "not superficial to belie a deeper continuity" of what he terms "popular authoritarianism." Using public confidence in political institutions as "a more reliable measure of regime legitimacy," his survey data shows "strong regime support" among Chinese citizens. ${ }^{50}$ However, by repeating the standard depiction of China's "weak political institutions" in an "underdeveloped civil society," he undermines his own theory which could have been more coherently related to a tradition of the communist revolution. Consequently, he ignores unmet expectations the ostensibly socialist state still entices. And he accepts the mass line at face value, disregarding the hollow rhetoric in an entirely different political ecology of party-mass relations. ${ }^{51}$ Again, the shifting contradictions of a tortuous trajectory have to be carefully delineated; nothing of an inert, nonspecific identity of Chinese communism can be indiscriminately applicable across the board.

The making, unmaking, and remaking of China's political economy since 1949 should have burst the notion of "one party rule." Nor is the contrast between a much maligned Maoist era and a much applauded Dengist reorientation up to the task of explaining regime legitimacy and durability. Any explanation will at best be incomplete until the contradictory legacies of Chinese communism are more soberly assessed. The state's altered support base is essentially a matter of class power, involving both adaptive cultivation of new economic elites and iron-fist approaches to protest and dissent. By the same weight of historical logic, the party's internal decay and loss of its founding ideological vision and commitment, and collusion with capital, would do more than any outside force ever could do to destroy the regime. In this sense, the question about communist stability in China is itself questionable as the communist identity of Chinese

47 Shambaugh 2016, 36-39, 99. For most China watchers, "Maoist conservative" also sounds like a contradiction in terms.

48 Dickson 2016, 312.

49 Nathan et al. 2013.

50 Dickson and his collaborators' fieldwork yielded similar results (2016) and they addressed certain doubts raised by skeptics, but the reliability and interpretation of such polling data remain questionable.

51 Tang 2016, 17, 99, 102-3, 160. Reinventing political culture, he seemed to not care if it was once "a dirty word in contemporary Chinese studies" (Cheek 1998, 231). He even revived the notorious notion of "civic culture" $(161,166)$ intended to promote a "right mix" of participation, passivity, and deference. 
power trembles. However, if other political orders would have collapsed in a similarly acute crisis situation, the Chinese case does require an explanation. That the Party stays in power is not primarily because the country's economy continues to grow, but is more attributable to a residual social reliance on its credentials and organizational capacities accumulated in earlier revolutionary and socialist struggles. This historical promise has so far worked to the extent that cracks within the leadership are more or less held in check, resentment against local wrongs are insulated from central intentions, and social policies in one way or another respond to common outcries, consultative deliberations, and pressure groups. ${ }^{52}$ Indeed, on the scale of world history, if the twentieth century was dominated by the trajectory of the Russian Revolution, the twenty-first will still "be shaped by the outcome of the Chinese Revolution." 53

\section{The Function of China in Political Science}

As the notion of a singular modernity has enjoyed a post-communist revival, the social science disciplines have evoked modernization theory dressed up as globalization, with the latter now "a resource for the reevaluation and reorganization of the social and the human sciences." 54 If the West-East dichotomy refuses to recede, it is because the PRC politically more than culturally causes pain. Communist politics, actual or nominal, is what makes everything go awry. That is, the barrier to a scholarship of critical nuance, like the works capable of elucidating revolutionary modernity sampled earlier, is not so much Eurocentrism as it is a new manifestation of anti-communism. The entrenched organization of knowledge within political science requires a polarization between the modern and premodern/yet-to-be-(fully) modernized, the developed and backward, the democratically settled and unsettled, the free and the not free, and so on. Negative mirror images of an inferior other are needed as a foil for positive significations of what is supposed to be "normal" development.

Worse, the unpredictable (read irrational) communist regime mixed with diverse local cultures in China has compressed homegrown and implanted traits in its deviations from more typical political formations. ${ }^{55}$ Exclusion and self-exclusion in the production of such eccentricities are handy to ensure that Euromodern universality will not be disturbed. China, which defies these generalizations, is by definition an outlier in political science inquiries. However, an alternative Sino-exceptionalism is not tenable. Rather than objectivity, unfulfilled are subjective projections, which then render it practically permissible to jump from exceptional to pathological. Just like contrasting the "normal" with an "abnormal," these binaries are mutually dependent, reinforcing, and encoded in

52 See Saich 1994, 261 on leaders playing on fear of chaos; Zhao 2009 on "performance legitimacy;" Shue 2010 on a central-local bifurcation of the state in Chinese perception; and Levitsky and Way 2013 on connections between regime cohesion and repression. 53 Anderson 2010, 59.

54 Dirlik 2007, 1-2, 6. Globalization has revamped modernizationist claims in social sciences as "both a continuation and a disavowal" (Dirlik 2011, 16).

55 Relevant here is the articulation of Sinified Marxism in line with the classical Marxist thesis of uneven and compressed development, recognizing both anticipated "privilege" and predestined anguish of backwardness. 
the knowledge construction and transmission of meaning. The Foucaultian genealogy of insanity or "episteme of pathologicalization" and its suppression is, alas, analogical: The "selective formation of concepts" makes converses of discipline and power, ideology and science. ${ }^{56}$

The word "madness" has indeed been freely employed to describe nations and societies judged inept at modern reason, as found in contemporary academic publications on episodes of the PRC history. "What makes an event such as the Cultural Revolution seem so hopelessly insane," in Arif Dirlik and Maurice Meisner's critique, is partly its presumptuous challenge to the party-state itself; hence, the CCP's embrace of market reforms "in its return to the ideologically prescribed normal stream, appears as a return to sanity." ${ }^{57}$ In fact, as this return to sanity deepens, even a radicalized transition to privatization and liberalization cannot satisfy the set criteria of normality. Insofar as policies do not lead to a wholesale economic restructuring and a political glasnost, any changes not in step with globally scaled expectations are judged either wrong or useless.

China's legal reforms, for example, are presumed not to be credible because these have proceeded under the Party's directives and claimed Chinese characteristics. Political scientists still tend to believe what Lucian Pye pointed out five decades ago: "the ultimate test of nationhood, and of membership in the community of modern states, depended upon the introduction of a Europeanized legal system." ${ }^{58}$ Ignored by the followers of this doctrine is the grassroots perspective of Chinese citizens. More incisive critics within the PRC see the rule of law as a legitimate goal in light of past lawless excesses as well as the present ills of a misguided and corrupt legal and penal system. When migrant workers are tried for having "disturbed public order" by rallying over their wage arrears, or leaders of protesting villagers over their lost land get arrested and charged with "corruption," we know that at issue is not procedures but the morality of legality: What laws? Whose judiciary? The priority of substance over form is a legacy of the Chinese Revolution, which created a sovereign people, hence the democratic presupposition about the nature of law being determined by the people as collective lawmakers. Clearly, in China neither legal reform nor political democratization can be pursued separately from social rights and justice.

A telling example of resisting an imposed legal formalism is the dilemma faced by workers under an increasingly legalized labor regime, under which the law is a system of selective protection as much as control and mystification. ${ }^{59}$ While atomized workers in a commodified and non-unionized labor force have sought arbitration through depoliticized litigation and lawsuits, they are already robbed of any institutionalized

56 Social scientists are empowered by their disciplinary training, like nineteenth century neurological doctors by their medical training, in exerting specialized and institutionalized authority over the abnormality of either a category of subject matter or a group of restrained patients. Such treatment involves selections of what to preserve, eliminate, or invent as a matter of "scientific" rules. See Foucault 1965, Canguilhem 1978; Durkheim 1938, ch.3. Also detectable in such exercises is naked racism.

57 Dirlik and Meisner 1989, 16-18.

58 Pye 1966, 115.

59 Lee 2007; Chen 2007. See also O'Brien and Li 2006; Friedman and Lee 2010; Pun and Chan 2012. 
power. Once law (such as the 2007 Labor Contract Law) has replaced state representation of working class interests, or a "legal state" has replaced a "workers' state," individual plaintiffs and isolated court rulings have no way to counter capital and management. This gap between ideational legal rationality and the remnants of egalitarianism and social justice is instructive. Local conditions demand the moral/institutional and the formal/substantial to cohere. Much the same can be said about farmers' "rightful resistance" justified on the government's own promises and policy statements. ${ }^{60}$ The social rights of common folks bestowed by the Revolution are not yet vanished, nor are they dismissible in the popular consciousness.

In the same vein, "democracy" and "civil society" are the discipline's dominant legitimating symbols, and hence constantly evoked to delegitimize alternative paths and visions. Although some expansion of (semi) autonomous social activism since 1989 has been welcomed in a flourishing literature on civil society, government restrictions and crackdowns are all that count in how political scientists explain state-society antagonism. An important oversight here is class polarization and conflicts within society: a market dictatorship makes civic autonomy self-deceptive. ${ }^{61}$ The exploitative and subordinate relationships that occur in what is an "uncivil" society discredit the anti-state ideological purchase of an all-virtuous civil society both conditional and constitutive of democracy. To idealist liberals, most irritating is the absence in the PRC of structural political reform (or "regime change") to match a marketized economy and desirable constitutionalism. But such a perspective obscures the reality of a state-capital alliance in the first place. This reality is precisely what renders the benchmarks of liberal democracy locally suspicious. Any political reforms that would only ease the way for further private concentration of power, wealth, and resources by legal and other means will appear undemocratic and popularly unacceptable. That serious democratic reconstruction is requisite in China is not the issue; the meaningful question is what kind.

Illuminating in this context is the conceptual vicissitude of "totalitarianism."62 This notion has been widely resisted by China specialists because of its ideological baggage and failure to capture the specific features of a participatory Chinese politics. Yet "authoritarianism" with ever more adjectives indicative of reification appears just as imperfect. ${ }^{63}$ A less prevalent political science concept is "total politics." It depicts a

60 O'Brien and Li 2006.

61 Particularly stimulating is the Gramscian insight on a civil society buttressing political society as the state. See Cheek 1998, 236-238. For China's phenomenal bureaucratic capitalism and interpenetration of state and society, governments and businesses, see Solinger 1992, Dickson 2003, Huang 2008, and Au 2013.

62 Goodman 1984, Introduction. Communist totalitarianism has been regularly taken as indistinguishable from Nazism and Fascism. Furet, for example, typically read into Hannah Arendt this conflation. He nevertheless admits that the concept "tells us nothing of what those [communist] regimes owed to the circumstances of their development" (1997, 137, 161).

63 As Wang points out, if very different political regimes in Chinese history, including dynastic courts, warlords, the Nationalist rule, the Maoist revolutionary party, and Dengist reformsist state are all "authoritarian," the category loses its analytical use (2011, 302). Such added adjectives as "fragmented and decentralized", "negotiated or 
winner-takes-all game in which the leaders are nevertheless obliged to launch necessary reforms due to internal "legitimating constraints." Taking into account this ideological mechanism allows for the demands from within and below in the rulers' own terms. ${ }^{64}$

If few political scientists foresaw the disintegration of the Soviet bloc, now most all accept as common knowledge an era of "post-totalitarianism." Astounding is not capitalist triumphalism per se, but the sweeping attacks on everything once communist, as though the political experiences of fully one-third of the world's population were nothing but suffering and ultimately worthless. Ironically, as a highly ideological and selective self-knowledge about servile fools or doomed victims has been construed as collective memories, it has boosted the disciplinary power/knowledge nexus associated with those Cold War preoccupations which have no reason to outlive history. ${ }^{65}$

\section{Discipline, Power, and Transformative Scholarship}

China is undertaking yet another great transformation. Its ruling political class has even signalled its intention of turning the country into a leader of free trade following the U.S. election of 2016. Despite an emerging and refreshing scholarship on China's "one belt, one road" strategy, ${ }^{66}$ political science has hardly caught up to clarify and steer this turn. On the other hand, it is also fair to ask if China is moving ever faster toward compliance with Atlantic-cum-global norms. Has not every disciplinarily standard been vindicated, after all? Have previously observable conceptual discrepancies been smoothed out by history, so to speak; or is it that disciplinary inadequacies have only been magnified in a brave new world?

This is the best and worst of times for the globalization of knowledge. In one scenario, an eventual completion of the political science parameters can now seal both knowledge, sophisticatedly canalized, and ideology, universally uncontested - even if the two are never separable in the foundation of political science. In another scenario, causes and effects no longer rule out atypical polities, but the differences are presented as culturally incompatible. In either case, the trick remains to let anormalies make the norms validate preexisting disciplinary sanctions. Nothing less than questioning the worldview upon which political science rests (Euromodernity in its universalist pretensions) could engender a decisive reversal. Only then could the discipline be open to legitimate contributions from fresh fieldwork and independent thinking outside of this foundation. This would mean a deserved recognition of the critical scrutiny of disciplinary knowledge embarked upon decades ago from the professional periphery of China studies, as briefly

bargained," "adaptive," "responsive," "consultative," “deliberative," "populist" and "resilient" mitigate but do not resolve the problem.

64 Tsou 2000. See also Meisner 1996, ch. 11 on the revival of "bureaucratic capitalism" (a characterization in the Chinese revolutionary vocabulary) in today's China as a peculiar variant of state capitalism.

65 Portrayals of a despotic, fanatical, criminal, and murderous Mao era in Chinese, English, and other languages have surpassed even the worst Cold War propaganda (Gao 2008). Globally, even on the Left, conversations about historical communism often begin with the pretext, "although socialism has failed...."

66 Callahan 2016; Nolan 2017, chs 1 and 2. 
mentioned earlier. The project may now gather new momentum, enabling political science to better understand, explain, and predict developments outside its regional and conceptual concentrations. The following could be the tasks ahead.

First is a more holistic disciplinary outlook forged by self-critical reflection on the pitfalls of political studies. With a commonsense recognition that moral legitimacy is central to society and politics and thereby to the modalities of the social sciences, $\mathrm{C}$. Wright Mills long ago emphasized the role of imagination in sociological craftsmanship. Cherishing the Weberian elevation of science as a vocation, he also stressed that good social science becomes good politics when it generates open and public discussions. ${ }^{67}$ Drawing on the large-scale experiences of those not conforming to the narrow disciplinary norms and expectations could be especially helpful.

This is not to endorse any ethnocentric approach, which would only affirm "western" biases by replicating their penchant for dichotomization. ${ }^{68}$ Analytically, it would also be mistaken to treat China and Chinese identity as intrinsically coherent. Tension between official and popular China, and within each of these fuzzy categories, is one example of how this country is politically diverse and endlessly complex, rendering monolithic representations of little value. Sinocentrism is in fact barely operational in an intellectual environment of post-Sinological determinism, and also complacent, being not a defensible alternative to the "colonizer's model." Against this backdrop, the call for an "indigenization of political science" by some leading Chinese scholars is forceful but implausible. ${ }^{69}$ What is needed is a genuinely universal (and, for that matter, scientific) discipline. For only the latter will be capable of grasping and absorbing local knowledge and contributions in its unified analytical, theoretical, and coding frameworks.

Secondly, to amend the polarity between unredeemable deviations and indisputably normative conceptions and values, political science must at long last broaden its empirical base beyond the West. This is not a matter of expanding already inclusive "area" studies or comparative politics. Nor is it just about examining hitherto unexamined presuppositions, incorporating unfamiliar political actors and ideas, and encouraging problem-driven research. Rather, testable theories can now be drawn from many widely engaged fields and information processed in the same breath of disciplinary perspectives and framing. Indeed, "a general framework of analysis is only acceptable if

67 Mills 1959. See Todd Gitlin in Mills 1959, 234. See also a critical case study by Johnson 1997. The most radical proposal from the prominent historian and political scientist Bruce Cumings in rethinking the boundaries of area and discipline is to "abolish the social sciences and group them under one heading: political economy" $(1997,26)$. 68 In Cumings' astute critique, the "new Orientalist craze" of nativist self-othering is only superficially resistant as "another hyperactive spasm" of Western hopes and fears about the East $(2011,185)$. Vukovich shows how in a twist of Orientalism, the logic of difference is shifted to one of sameness $(2012,23-24)$.

69 See the debate carried in the Journal of Chinese Political Science special issues on "the state of the field: political science and Chinese political studies," 14 (3), 14 (4) and 16 (3), 2009-2011. The essays are collected in Guo 2014. Representatively, the debate is characterized in part between "scientification" or Westernization and "indigenization" of Chinese political studies. An inspiration for the latter is "theoretical autonomy" (Huang 1991, 335). 
it permits, and is shown to permit, an effective analysis of particular cases." ${ }^{, 70}$ Moreover, as Clifford Gertz argued, if the Third World escapes "the established categories of our understanding," then it is not just policies and explanations that are inadequate, "it is the conceptual equipment we use to think them with."71 Overcoming outmoded rigidities will nurture a robust scholarship committed to universally resonant theories. This will in turn help improve disciplinary symbols in the public sphere of concerned discursive communities. Insofar as one-way assimilation is an utter illusion, and given China's size and complicated transformations, the Chinese case "represents something akin to a laboratory for social science." More pointedly, it holds "the promise of making a significant impact on theory-building in political science." 72

Potential institutional innovations in China might transgress some theoretical limits of schematized development and democratization. ${ }^{73}$ For example, the plasticity of Chinese national identity is conceptually stimulating. In addition, although China partakes in global competition over resources, the Chinese ways of investing overseas are still distinguishable from those of old colonial powers. ${ }^{74}$ The possibility of reinventing approaches more eco-environmentally sustainable and more beneficial to the developing world and international cooperation is not closed. This raises an interesting question about whether the modern conception of national sovereignty (in unitary or variously federalist state and supra-state forms) is amendable. Multiple systems within one country and territories shared between sovereign political communities (both of which were elements in China's historical regional structure) are pertinent to Beijing's contemporary policy contemplations. Something of practical merit might be found in these approaches for seemingly unsolvable land and maritime disputes.

Things of course could also turn perilous, as predicted by advocates of the "rising China" syndrome. Regardless, empirical intensity and extensity as well as buttressed interpretative and methodological leeway are both desirable and achievable. Gaining from a more open and integrated mode of inquiry, political science could transcend itself by further collaboration with other humanistic and social science branches. Scholars in Chinese studies within the political science profession have been drawing analytical and conceptual insights from other disciplines for a long time.

\section{${ }^{70}$ Breuilly 1993, 2.}

71 Geertz 2005, 37-38. Similarly, Weiner's contextualist "is sensitized to look at a wider range of relationships than the political scientist who is not an area expert." If he has problem applying theory, "it is not because he is perversely committed to the uniqueness of his region, but because he often finds the general theories do not work or are at a level of generalization that makes them trivial" $(1975,148)$.

72 Harding 1994, 701; Little 1989, 3. See also Perry on the hope of turning the China field from a "consumption domain" (relying on external concepts and theories) into a "production domain" $(1999,253)$. Speaking for political scientists in China, Wang argues "for the day when we become the producers and exporters of ideas, theories, and methods" (2011, 314).

73 An influential advocate of institutional innovation in China, from property rights regime to a mixed constitution, is the political scientist Cui Zhiyuan, who draws inspiration from the Brazilian thinker Roberto Unger among others. See Cui 1997. 74 Lee 2014; Sautman and Yan 2015; Brautigam 2015. 
Thirdly, since empirical evidence is not only about collection but also selection, and is subject to interpretation, honest awareness of the politics of data and narratives is a prerequisite for scholarly efficacy. Grand narratives - however disguised or hidden, or intentionally rejected - exist; and they affect, if not directly dictate, observations, representations and explanations. The heated debates over the human cost of China's land reform, Great Leap policies, and Cultural Revolution illustrate how arguments on all sides are highly dependent on rival master narratives. Events, numbers, and archival documents can be manipulated to fit preset, often emotionally-charged conclusions. What has disappeared is a liberal consensus on the basic premise of the definitive historicity and fundamental justice of the communist revolution in China: 1949 was of universal significance for liberation and modernization in line with other great social revolutions. Without such a consentient premise no failure or crime committed by the revolutionaries along their valiant course to power can be thoroughly exposed and criticized.

Conscious efforts in the study of Chinese politics have begun to make unprecedented strides toward disciplinary reform. An example, however depoliticized, is research on the legacy of communist wartime "guerrilla style" tactics. The CCP sets the goals and with its flexible cadre system can incrementally pursue experimental policies in pilot projects. In combination with newly institutionalized mechanisms, this approach facilitates a more open, pluralized, and adjustable style of governance. ${ }^{75}$ Here what political modernization theorists do not recognize is empirically evident. Another example is the mucky "China model" debate and its unpredictable repercussions. Breakthroughs are to be expected in the contours of conventional as much as inventive disciplinary engagements concerning interactions among state, market forces, and society, and their translocal and transnational intervening agencies at all levels. How and why has China retained thus far a core of equal land rights notwithstanding continuing rural disorganization and urbanization $?^{76}$ Where to situate China globally, and what is the relationship between the PRC state and (Chinese) international capital's global value chain which fuels a surging transformative politics inside and outside of the PRC? How to explain the government's stress on "self-confidence" while imposing ever tightened survelance, censorship, and suppression? In the end, can China solve its own problems before it may offer anything appealing to a world trapped in inequalities, social conflicts, and ecological predicaments? Such open-ended questions provide political science with an open opportunity for rejuvenation.

By the same logic, finally, any discursive "regime of truth" rooted in a given social power structure is dubious and refutable. ${ }^{77}$ The political science structure of

75 Heilmann 2017. See also Nathan 2003; Heilmann and Perry 2011; Saich 2016; and Tsai's study of China's market enabling "adaptive informal institutions" (2007)..

76 China's collective ownership and management of land differs from either state/national landholding or customary/communal land regimes. In sharp contrast with developmental hurdles caused by unequal land relations and landlessness elsewhere in the global south, the Chinese system has played a pivotal role in development. Research in this area is growing in response to rapid land commodification as a threat to food security and the livelihood of the world's "last peasantry."

77 For Foucault, each society has its own regime or general politics of truth, referring to the types of discourse such a regime accepts and makes "true." Such a regime of truth is 
knowledge cannot be divorced from its social edifice of political economy. The former as an indispensable component in the function and legitimation of the latter governs much of the thinking and writing - however critical this may be - about local and global politics. In other words, as political science necessarily incorporates the conditions of human existence and is constitutive of and constituted by a dominant ideology, it forecloses any far-reaching revisions. However, nothing is immune to change. Since it was not very long ago, in the postwar stabilization, that this regime of truth seized on a favorable conjunction of situations to fortify itself, we may expect that under drastically altered circumstances its hold on power will loosen. The same can be said about its supporting institutional networks and symbolic capital, and research, educational, and information-technological systems.

Above all, the presumption of a privileged and authoritative knowing subject must be refuted. ${ }^{78}$ To be sure, the social sciences and their foot soldiers are constrained by our all-encompassing epochal conditions. But any single truth, sole horizon, or exclusive access to reason and progress must be contested. Proliferate modes of inquiry are necessarily open and manifold, leaving room for paths not taken, ideas unimagined, and undertakings that may at the moment seem undisciplined. If the assumption of a capitalist telos is the primary source of disciplinary limitations, a different meta-historical consciousness can anchor more balanced prospects. A renewal is therefore possible, as a front in the Gramscian counter-hegemonic struggle. Again, such a reformist proposal is not about cultural specificity or Chinese characteristics (which have become euphemist excuses) but a challenge to the "tunnel history" of capitalist universality which continues to underpin political science. For an intellectual undoing of not exactly Western but capitalist-centrism, the unlocked case of China is especially useful. Just as Chinese politics must be studied in a unified disciplinary framework, by the same token, such studies will catalyze and inspire disciplinary rethinking, in which alternative aboriginalities might be of potentially universal significance.

Collective effort by generations of dedicated scholars is now opening certain cognitive and conceptual possibilities for China to exert disciplinary influence on critical inquiries. In the end, even if there is no eventual reconciliation between science and culture, objectivity and ideology, the politics of knowledge and the knowledge of politics, a rigorous counterhegemonic scholarship can be consciously fostered. It is with such open-mindedness and self-reflexive energy that our "noble science of politics" should be vested.

\section{Acknowledgements}

"not merely ideological or superstructural," but a condition of social formation (1980, 111-113, 131-133). This point is best exemplified by modernization theory. As Theodore Lowi, former APSA President admitted, every regime seeks to establish a political science discipline consonant with its own interests and thus there cannot be any single truth or one science of politics $(1992,1)$.

78 Worth mentioning is the Maoist "revolution in education" which went a great deal farther than the Fucaultian formula of power/knowledge. 
The author is grateful to the editor and anonymous reviewers of CAS for their critical and constructive feedback.

\section{About the Author}

Lin Chun is an Associate Professor of Comparative Politics at the London School of Economics and author of The British New Left (1993), The Transformation of Chinese Socialism (2006), China and Global Capitalism (2013) and, in Chinese, Reflections on China's Reform Trajectory (2008).

\section{References}

Adcock, Robert, Mark Bevir and Shannon C Stimson, (eds.) 2009. Modern Political Science: Anglo-American Exchanges since 1880. Princeton: Princeton Universtiy Press.

Almond, Gabriel A. and Laura Roselle. 1990. "Model Fitting in Communism Studies." In A Discipline Divided: Schools and Sects in Political Science, edited by Almond, 170-224. London: Sage.

Anderson, Perry. 2010. “Two Revolutions.” New Left Review 61: 59-96.

Angle, Stephen. 2005. “Decent Democratic Centralism.” Political Theory 33 (4): 518-546.

Au, Loong Yu. 2013. China's Rise: Strength and Fragility. London: Merlin Press.

Bailey, Anne M. and Josep R. Llobera. 1981. The Asiatic Mode of Production: Science and Politics. London: Routledge.

Barlow, Tani E. 1997. “Colonialism’s Career in Postwar Studies.” Positions 1 (1): 224-267.

Baum, Richard. 2007. "Studies of Chinese Politics in the United States." In China Watching: Perspectives from Europe, Japan and the United States, edited by Robert Ash, David Shambaugh and Seiichiro Takagi, 147-167. London: Routledge.

Bauman, Zygmunt. 2000. Liquid Modernity. Cambridge: Polity Press.

Bevir, Mark and R.A.W. Rhodes. 2006. "Defending Interpretation.” European Political Science 5: 69-83.

Blecher, Mark. 1997. China Against the Tide: Restructuring through Revolution, Radicalism and Reform. London: Pinter.

Brautigam, Deborah. 2015. Will Africa Feed China? Oxford: Oxford University Press.

Breuilly, John. 1993. Nationalism and the State. Manchester: Manchester University Press. 
Brook, Timothy and Gregory Blue. 1999. China and Historical Capitalism: Genealogies of Sociological Knowledge. Cambridge: Cambridge University Press.

Callahan, William. 2016. "China's Asian Dream: The Belt Road Initiative and the New Regional Order.” Asian Journal of Comparative Politics 1 (3): 226-243.

Canguilhem, Georges. 1978. On the Normal and the Pathological. Boston: Dordrecht.

Carlsen, Allen and Mary Gallagher, Kenneth Lieberthal, and Melanie Manion, (eds.) 2010. Chinese Politics: New Sources, Methods, and Field Strategies. New York: Cambridge University Press.

Cheek, Timothy. 1998. "From Market to Democracy in China: Gaps in the Civil Society Model." In Market Economics and Political Change, edited by Juan Lindau and Cheek, 219-254. Lanham, MD: Rowman \& Littlefield

Chen, Feng. 2007. "Individual Rights and Collective Rights: Labor's Predicament in China." Communist and Postcommunist Studies 40: 59-79.

Cohen, Paul. 2003. "The 1949 Divide in Chinese History." In Twentieth-Century China: New Approaches, edited by Jeffrey Wasserstrom, 27-36. London: Routledge.

Collini, Stefan, Donald Winds, and John Burrow, (eds.) 1983. That Noble Science of Politics: A Study in 19th Century Intellectual History. Cambridge: Cambridge University Press.

Condorcet, Antoine-Nicholas de. 1955. Sketch for a Historical Picture of the Progress of the Human Mind. New York: Noonday Press.

Cui, Zhiyuan. 1997. "Introduction" in Roberto Unger, Politics: The Central Texts, v-vi. London: Verso.

Cumings, Bruce. 1997. "Boundary Displacement: Area Studies and International Studies during and after the Cold War." Bulletin of Concerned Asian Scholars 29 (1): 6-26.

Cumings, Bruce. 2011. “The 'Rise of China'?” In Radicalism, Revolution, and Reform in Modern China, edited by Katherine Lynch, Robert Marks, and Paul Pickowicz, 185-207. Lanham, MD: Lexington.

Dawson, Raymond. 1964. The Legacy of China. Oxford: Clarendon.

Dickson, Bruce. 2003. Red Capitalists in China: The Party, Private Efentrepreneurs, and Prospects for Political Change. Cambridge: Cambridge University Press.

Dickson, Bruce. 2016. The Dictator's Dilemma: The CCP's Strategy for Survival. Oxford: Oxford University Press. 
Dirlik, Arif. 2007. Global Modernity: Modernity in the Age of Global Capitalism. London: Routledge.

Dirlik, Arif. 2011. Culture and History in Post-Revolutionary China: The Perspective of Global Modernity. Hong Kong: Chinese University Press.

Dirlik, Arif and Maurice Meisner, (eds.) 1989. Marxism and the Chinese Experience. Armonk, NY: M.E.Sharpe.

Dittmer, Lowell. 1983. "The Study of Chinese Political Culture." In Methodological Issues in Chinese Studies, edited by Amy Wilson, Sidney Greenblatt, and Richard Wilson, 51-68. New York: Praeger.

Duara, Prasenjit. 1995. Rescuing History from the Nation: Questioning Narratives of Modem China. Chicago: University of Chicago Press.

Durkheim, Emile. 1938. The Rules of Sociological Method. New York: Free Press.

Easton, David. 1969. "The New Revolution in Political Science.” American Political Science Review 63 (4): 1051-1061.

Esherick, Joseph. 1995. "Ten Theses on the Chinese Revolution.” Modern China 21 (1): 4576.

Foucault, Michel. 1965. Madness and Civilization: A History of Insanity in the Age of Reason. New York: Pantheon Books.

Foucault, Michel. 1980. Power/Knowledge: Selected Interviews and Other Writings, 19721977, edited by Colin Gordon. New York: Pantheon Books.

Friedman, Eli and Ching Kwan Lee. 2010. "Remaking the World of Chinese Labor: A 30Year Retrospective.” British Journal of Industrial Relations 48 (3): 507-533.

Furet, Francois. 1997. The Passing of an Illusion: The Idea of Communism in the End of the 20th Century. Chicago: University of Chicago Press.

Gao, Mobo. 2008. The Battle for China's Past: Mao and the Cultural Revolution. London: Pluto.

Geertz, Clifford. 2005. "What Was the Third World Revolution?” Dissent 52 (1): 35-45.

Gellner, Ernest. 1983. Nations and Nationalism. Oxford: Blackwell.

Gilman, Nils. 2003. Mandarins of the Future: Modernization Theory in Cold War America. Baltimore: Johns Hopkins University Press. 
Goodman, David (ed.) 1984. Groups and Politics in the People's Republic of China. Armonk: M E Sharpe.

Goossaert, Vincent and David Palmer, (eds.) 2011. The Religious Question in Modern China. Chicago: University of Chicago Press.

Guo, Sujian. 2014. Political Science and Chinese Political Studies: The State of the Field. New York: Springer.

Hann, Chris (ed.) 1998. Property Relations: Renewing the Anthropological Tradition, Cambridge: Cambridge University Press.

Harding, Harry. 1981. Organizing China: The Problem of Bureaucracy, 1949-76. Stanford: Stanford University Press.

Harding, Harry. 1994. "The Contemporary Study of Chinese Politics: An Introduction." China Quarterly 139: 699-703.

Heilmann, Sebastian, (ed.) 2017. China's Political System. London: Rowman \& Littlefield.

Heilmann, Sebastian and Elizabeth Perry, (eds.) 2011. Mao's Invisible Hand: The Political Foundations of Adaptive Governance in China. Cambridge, MA: Harvard University Press.

Hirschman, Albert. 1970. "The Search for Paradigms as a Hindrance for Understanding." World Politics 22 (3): 329-343.

Huang, Philip. 1991. "The Paradigmatic Crisis in China Studies: Paradoxes in Social and Political History." Modern China 17 (3): 299-341.

Huang, Yasheng. 2008. Capitalism with Chinese Characteristics: Entrepreneurship and the State. Cambridge: Cambridge University Press.

Huntington, Samuel. 1968. Political Order in Changing Societies. New Haven: Yale University Press.

Huntington, Samuel. 1975. "Political Science, American Area Studies, and their Paradigms of American Politics." In Political Science and Area Studies: Rivals or Partner, edited by Lucian Pye, 48-77. Bloomington: Indiana University Press.

Johnson, Chalmers. 1997. "Preconception vs. Observation, or the Contributions of Rational Choice Theory and Area Studies to Contemporary Political Science." PS: Political Science and Politics 30 (2): 170-174. 
King, Gary, Robert Keohane, and Sidney Verba. 1994. Designing Social Inquiry: Scientific Inference in Qualitative Research. Princeton: Princeton University Press.

Kraus, Richard Kurt. 2012. The Cultural Revolution: A Very Short Introduction. Oxford: Oxford University Press.

Lampton, David. 1987. "Chinese Politics: The Bargaining Treadmill." Issues and Studies 23 (3): 11-41.

Landes, David. 1998. The Wealth and Poverty of Nations: Why Some are so Rich and Some so Poor. New York: Norton.

Lee, Chin Kwan. 2007. Against the Law: Labor Protests in China's Rustbell and Sunbell. Berkeley: University of California Press.

Lee, Ching Kwan. 2014. “The Specter of Global China.” New Left Review 89: 29-65.

Leibold, James. 2013. Ethnic Policy in China: Is Reform Inevitable? East-West Center: Policy Studies 68.

Levitsky, Stephen and Lucan Way. 2013. "The Durability of Revolutionary Regimes." Journal of Democracy 24 (3): 5-17.

Lindblom, Charles. 1977. Politics and Markets: The World's Political-Economic Systems. New York: Basic Books.

Little, Daniel. 1989. Understanding Peasant China: Case Studies in the Philosophy of Social Science. New Haven: Yale University Press.

Lowi, Theodore. 1992. "The State in Political Science: How We Become What We Study." American Political Science Review 86 (1): 1-7.

Mackerras, Colin P. 2010. “Tibetans, Uyghurs, and Multinational 'China': Han-Minority Relations and State Legitimation." In Chinese Politics: State, Society and the Market, edited by Peter H Gries and Stanley Rosen, 223-242. London: Routledge.

MacIntyre, Alasdair. 1973. "Is a Science of Comparative Politics Possible?” In Philosophy, Politics and Society, edited by Peter Laslett, W.C. Runciman, and Quentin Skinner, 260279. Oxford: Oxford University Press.

Macpherson, C. B. 1962. The Political Theory of Possessive Individualism: Hobbes to Locke, Oxford: Oxford University Press.

Macpherson, C.B. 1966. The Real World of Democracy. Oxford: Oxford University Press. 
Marquis, Jefferson. 2000. "The Other Warriors: American Social Science and Nation Building in Vietnam.” Diplomatic History 24 (1): 79-105.

Meisner, Maurice. 1996. The Deng Xiaoping Era: An Inquiry into the Fate of Chinese Socialism, 1978-94, New York: Hill \& Wang.

Mills, C. Wright. 1959. The Sociological Imagination. Oxford: Oxford University Press.

Nathan, Andrew. 2003. “Resilient Authoritarianism.” Journal of Democracy 14 (1): 6-17.

Nathan, Andrew, Larry Diamond, and Marc Plattner (eds.) 2013. Will China Democratize? Baltmore: Johns Hopkins University Press.

Nolan, Peter. 2017. Understanding China: The Silk Road and the Communist Manifesto. London: Routledge.

Oakeshott, Michael. 2004. What is History and Other Essays. Exeter: Imprint Academic.

O’Brien, Kevin. 2011. "Studying Chinese Politics in an Age of Specialization.” Journal of Contemporary China 20 (71): 535-541.

O’Brien, Kevin and Lianjiang Li. 2006. Rightful Resistance in Rural China. Cambridge: Cambridge University Press.

Olson, Mancur. 1982. The Rise and Decline of Nations: Economic Growth, Stagflation, and Social Rigidities. New Haven: Yale University Press.

Peck, James. 2006. Washington's China: The National Security World, the Cold War, and the Origins of Globalism. Amherst and Boston: University of Massachusetts Press.

Pei, Minxin. 2015. "The Twilight of Communist Party Rule in China." The American Interest 11 (4). Accessed July 24, 2017: https://www.the-american-interest.com/2015/11/12/thetwilight-of-communist-party-rule-in-china/.

Perry, Elizabeth. 1994. "Introduction." In Popular Protest and Political Culture in Modern China, edited by Jeffrey Wasserstrom and Elizabeth Perry. Boulder, CO: Westview, 1-14.

Perry, Elizabeth. 1999. "Partners at Fifty: American China Studies and the PRC." Washington: Paper for conference on "Trends in China Watching," George Washington University. Accessed November 11, 2007: https://www2.gwu.edu/ sigur/assets/docs/scap/SCAP7Trends.pdf

Pun, Ngai and Jenny Chan. 2012. "Global Capital, the State, and Chinese Workers: The Foxconn Experience.” Modern China 38 (4): 383-410. 
Pye, Lucian. 1962. Politics, Personality, and Nation Building: Burma's Search for Identity. New Haven: Yale University Press.

Pye, Lucian. 1966. Aspect of Political Development: An Analytic Study. Boston: Little, Brown.

Rose-Ackerman, Susan. 2003. "Was Mancur a Maoist? An Essay on Kleptocracy and Political Stability.” Economics \& Politics 15: 163-180.

Ross, Dorothy. 1991. The Origins of American Social Science. Cambridge: Cambridge University Press.

Saich, Tony. 1994. "The Search for Civil Society and Democracy in China." Current History 93 (584): 260-264.

Saich, Tony. 2016. State-Society Relations in the People's Republic of China Post-1949. Leiden and Boston: Brill.

Said, Edward. 1978. Orientalism. New York: Pantheon Books.

Sanders, David. 2002. "Behaviouralism." In Theory and Method in Political Science, edited by David Marsh and Gary Stoker, 23-41. London: Palgrave.

Sartori, Giovanni. 1987. The Theory of Democracy Revisited. Chatham N.J.: Chatham House.

Sautman, Barry. 1999. "Ethnic Law and Minority Rights in China: Progress and Constraints." Law and Society 21 (3): 283-314.

Sautman, Barry and Yan Hairong. 2015. "Localizing Chinese Enterprises in Africa: From Myths to Policies." Hong Kong Institute of Science and Technology IEMS 5, 1-4.

Sautman, Barry. 2006. “Colonialism, Genocide and Tibet.” Asian Ethnicity 7 (3): 243-265.

Schurmann, Franz. 1966. Ideology and Organization in Communist China. Berkeley: University of California Press.

Selden, Mark. 1971. The Yenan Way in Revolutionary China. Cambridge, MA: Harvard University Press.

Seldon, Mark and James Boyce. 1992. "National Security and the Future of Asian Studies." Bulletin of Concerned Asian Scholars 24 (2): 84-96.

Shambaugh, David. 2009. China's Communist Party: Atrophy and Adaptation. Berkeley: University of California Press.

Shambaugh, David. 2015. “The Coming Chinese Crackup.” Wall Street Journal (March 6). 
Shambaugh, David. 2016. China's Future. Cambridge: Polity.

Shue, Vivienne. 2010. "Legitimacy Crisis in China?" In Chinese Politics: State, Society and the Market, edited by Peter H Gries and Stanley Rosen, 41-68. London: Routledge.

Skocpol, Theda. 1979. State and Social Revolution: A Comparative Analysis of France, Russia, and China. Cambridge: Cambridge University Press.

Solinger, Dorothy. 1992. "Urban Entrepreneurs and the State: The Merger of State and Society." In State and Society in China: The Consequences of Reform, edited by A.L. Rosenbaum, 121-141. Boulder, CO: Westvew Press.

Tang, Wenfang. 2016. Populist Authoritarianism: Chinese Political Culture and Regime Sustainability. Oxford: Oxford University Press.

Tilly, Charles. 1975. "Revolutions and Collective Violence." In Handbook of Political Science vol.3, Macropolitical theory, edited by Fred Greenstein and Nelson Polsby, 483555. Redding, MA: Addison-Wesley.

Tipps, Dean C. 1973. "Modernization Theory and the Comparative Study of Societies: A Critical Perspective." Comparative Studies in Society and History 15 (2): 199-226.

Tsai, Kellee. 2007. Capitalism without Democracy: The Private Sector in Contemporary China. Ithaca: Cornell University Press.

Tsou, Tang. 2000. "Interpreting the Revolution in China: Macrohistory and Micromechanisms.” Modern China 26 (2): 205-238.

Verba, Sidney. 1965. “Comparative Political Culture.” In Political Culture and Political Development, edited by Lucian Pye and Sidney Verba, 512-560. Princeton: Princeton University Press.

Vukovich, Daniel. 2012. China and Oritentalism: Western Knowledge Production and the PRC. London: Routledge.

Walder, Andrew. 2004. 'The Transformation of Contemporary China Studies, 1977-2002." In The Politics of Knowledge: Area Studies and the Disciplines, edited by David Szanton, 314-340. Berkeley: University of California Press.

Wallerstein, Immanuel. 1991. Unthinking Social Science: The Limits of Nineteenth-Century Paradigms. Cambridge: Polity.

Wang, Hui. 2010. "The Tibetan Issue between East and West: Orientalism, Ethnic Regional Autonomy and the Politics of Dignity." Chinese Sociology and Anthropology 42 (4): 730 . 
Wang, Shaoguang. 2011. "To 'Fall in Line' or to 'Grab': Thoughts on the Indigenization of Political Science.” Journal of Chinese Political Science 16 (3): 299-322.

Ward, Robert E. 1975. "Culture and the Comparative Study of Politics." In Political Science and Area Studies: Rivals or Partners? Edited by Lucian Pye, 23-47. Bloomington: Indiana University Press.

Wasserstrom, Jeffrey and Elizabeth Perry (eds.) 1992. Popular Protest and Political Culture in Modern China. Boulder, CO: Westview Press.

Weiner, Myron. 1975. "India: Two Political Cultures.” In Political Science and Area Studies: Rivals or Partners? edited by Lucian Pye, 133-151. Bloomington: Indiana University Press.

White, Gordon. 1983. "The Postrevolutionary Chinese State." In State and Society in Contemporary China, edited by Jeffrey Nealon, Victor Nee and David Monzingo, 27-52. Ithaca: Cornell University Press.

White, Hayden V. 1962. "Translator's Introduction", Carlo Antoni, From History to Sociology: The Transition in German Historical Thinking. London: Merlin.

Womack, Brantly. 1991. "In Search of Democracy: Public Authority and Popular Power in China." In Contemporary Chinese Politics in Historical Perspective, edited by Brantly Womack, 53-89. Cambridge: Cambridge University Press.

Zang, Xiaowei. 2012. "Scaling the Socioeconomic Ladder: Uyghur Perceptions of Class Status." Journal of Contemporary China 21 (78): 1029-1043.

Zhao, Dingxin. 2009. "The Mandate of Heaven and Performance Legitimation in Historical and Contemporary China." American Behavioral Scientist 53 (3): 416-433. 